\title{
OBITUARY
}

\section{Sir JAMES CRICHTON-BROWNE, M.D., LL.D., D.Sc., F.R.S.E., F.R.S.}

By the death of Sir James Crichton-Browne in his 98th year there has passed from our midst the Last of the Great Victorians, the Grand Old Man of Medicine and Psychiatry, the Orator of the Profession, the Senior Diplomate and Graduate of the Edinburgh Medical School and on the Medical Register, the Senior Fellow of the Royal Societies of Edinburgh and of London, and the greathearted and gifted physician, psychologist, reformer, scientist and author, who occupied a unique place in the medical, scientific and literary annals of his times. He died on the 3 ist January $193^{8}$, at Crindau, Dumfries, the peaceful retreat and home beside the beautiful Nith which he inherited from his parents.

James Crichton-Browne was born on the 29 th November $184^{\circ}$ at his mother's former home in 3 St John's Hill, Edinburgh, a cul-de-sac street off the Pleasance in the eastern outskirts of the city and close to the University. He was the eldest son of Dr William Alexander Francis Browne, then the physician-superintendent of the recently opened Crichton Royal Institution at Dumfries, and of Magdalene Howden Balfour or Browne. His parents named him after Dr James Crichton of Friars' Carse, who left the Crichton bequest (of about $£_{1} 100,000$ ), out of which the Institution was founded and endowed in honour of his memory by his widow, Mrs Elizabeth Grierson or Crichton, who was also chosen as the child's godmother. She was a very philanthropic and pious Scotswoman, and a lineal descendant of the Grierson of Lag and persecuter of the Covenanters portrayed in Redgauntlet; and in Some Early Crichton Memories, written about a year before his death, Sir James took the opportunity of paying, what he regarded as long overdue, a grateful tribute and panegyric to her memory. Sir James's younger brother, John Hutton Balfour Browne, also became famous as the eminent King's Counsel and leader of the Parliamentary Bar in his day. It is therefore of more than passing interest to say a few words about the parents of these distinguished sons, and of the early upbringing of the children in the home at Crichton House. Dr Browne, whose father was a young Lieutenant in the Cameronian Regiment and lost his life in the Peninsular War, was brought up by his grandfather in Stirling. He qualified in medicine in Edinburgh in 1826 and was Senior President of the Royal Medical Society in the session 1927-8. Dr Browne was a highly cultured man, of poetical temperament and practical mind. He was one of the pioneers and the ablest exponent of the humane and moral treatment of the insane at a 



\section{Obituary}

time when they were still generally regarded as peculiar kinds of criminals, requiring accordingly some kind of punishment; and in his own words the story of their treatment had for long been marked by " negligence, ignorance, callousness, and cruelty." He treated the mentally afflicted as fellow-creatures capable of appreciating the pursuits and pleasures of life of normal human beings; and many of the novelties which he introduced at the Crichton in occupational, recreational and social therapy (e.g. theatricals and concerts, and the historic monthly magazine, The New Moon, all produced by the patients, as early as I844), and which he described in his illuminating, eloquent and literary Annual Reports and other medical publications, became established practices later in progressive mental hospitals in this and other countries. A psychotherapist of penetrating insight, he was nevertheless equally also a physiotherapist in practice, firmly upholding that mental disease always has a bodily or physical basis. He and Dr Skae of Morningside were the most prominent medical psychologists in Scotland in their day. Following the passing of the 1857 Lunacy Act, Dr Browne and the late Sir James Coxe became the first two Medical Commissioners in Lunacy for Scotland, and, it may be added, by their broad vision and assiduous efforts, guided the policy of the General Board and of lunacy administration in Scotland, whereby the latter attained the leading position in the world for many years. Mrs Browne, wife of Dr Browne, was a daughter of Dr Andrew Balfour of Edinburgh, who afterwards took to printing and publishing and, along with Sir David Brewster, projected the Edinburgh Encyclopadia. Of Mrs Browne's four brothers, three were clever doctors (Thomas at Edinburgh, Andrew at Portobello, and James at Newcastle-on-Tyne), and the other was John Hutton Balfour, Professor of Botany and Dean of the Faculty of Medicine of Edinburgh University. Their grand-uncle was James Hutton (I726-I797), the first great British geologist, who settled in Edinburgh in 1768 , and wrote his "Theory of the Earth" at $3 \mathrm{St}$ John's Hill, now the site of a Corporation School. Mrs Browne was a rare type of the Scottish gentlewoman of her age, possessed of wide literary knowledge and refined taste, and, gifted with an exceptionally good memory, she often recited whole beautiful passages from her favourite Shakespeare and Burns and other poets. Some of the most notable figures in medicine, science and literature (Dr John Brown amongst them) were frequent guests of Dr and Mrs Browne at Crichton House, and their children were eager listeners in the cultured intellectual and literary atmosphere of their home. But their wise parents did not bring them up according to the prevailing tradition of those and later days that "children should be seen but not heard"; and, as Sir James once told the writer, they as children, far from being repressed and forbidden to talk at table, were encouraged to express themselves in conversation, and 


\section{Obituary}

on Sundays, after returning home from church, were asked to repeat the text and as many of the points of the sermon as they could remember. These early home influences, and the early cultivation of their attention, memory, and conversational powers, had marked and lasting effects upon the development of their young minds, as evidenced by the accuracy of thinking, tenacity of memory, clarity of expression, and vivacity of conversation so characteristic of the two distinguished sons in their after-lives.

James Crichton-Browne was educated and gained many prizes and honours at Dumfries Academy, Trinity College, Glenalmond, and the University of Edinburgh, to which he went in 1857 at the age of $I_{7}$, having already determined to adopt his father's profession and specialty. His Edinburgh teachers formed a brilliant galaxy, with such men as Lord Lister, Lord Playfair, Sir Robert Christison, Sir James Young Simpson, Syme, Goodsir, and the great Laycock, Professor of Practice of Physic, who had already begun to give his lectures on medical psychology, the first course on the subject in any medical school or university in the Kingdom. Crichton-Browne was a favourite pupil of Laycock. He joined the Royal Medical Society in his second year of studies (on I 9 th November 1858); presented his dissertation in his third year (on and December I 859 , 7 I pages) on "The Psychical Diseases of Early Life"; and in his fourth year-like his father in 1827 - he was elected Senior President, delivering his valedictory presidential address in March I86I on "The Clinical Teaching of Psychology." In both of these papers-written at the ages of 19 and 20 , nearly eighty years ago-he emphasised the need for more specialised attention being given to the study of mental diseases and psychology in the medical curriculum. His skill in debate and his oratorical gifts, so early displayed, made him the central figure of the Royal Medical Society in his day, when his contemporaries included such men as Robert Bannatyne Finlay (afterwards Lord Finlay) and many who later rose to the top of the medical profession in Edinburgh and in London. (He was made an Honorary Member of the Society on Ist March I888, and was its senior Fellow at his death.) CrichtonBrowne qualified L.R.C.S.E. in $\mathrm{I} 86 \mathrm{I}$, and graduated M.D. with Honours in I862, writing his thesis on "Hallucinations." After Edinburgh he continued his studies in London, where he qualified L.S.A. in $186_{3}$, and in Paris. Having decided to specialise in psychological medicine, and to do in England what his father had done for the insane in Scotland, he received his training as assistant medical officer in Devon, Derby, and Warwick County Asylums, and soon thereafter his promotion. In $\mathrm{I}_{86} 5$ he was appointed medical superintendent of the new Borough Asylum at Newcastle-on-Tyne, and gave a course of lectures on mental diseases at the College of Medicine in that city. 


\section{Obituary}

In 1866 he was promoted to the large West Riding Asylum at Wakefield as its medical director, and during the nine years of his great and assiduous work there, when he also lectured on mental diseases at the Leeds School of Medicine, he made "Wakefield" famous, not only as a model of administration and demonstration centre for asylum reforms, and as regards the enlightened methods of treatment which he introduced and extended, but also as the recognised centre of investigation in the country into the pathology of mental and nervous diseases. This he effected by the establishment of a research laboratory in neuropathology, the first of the kind in the Kingdom, which soon attracted the notice and visits of neurologists; and by the publication of the historic West Riding Asylum Medical Reports, edited by himself and first appearing in $187 \mathrm{I}$, containing the results of the clinical and pathological investigations of the wealth of material available, and including many contributions by distinguished physicians and neurologists, and in particular the accounts of Sir David Ferrier's classic experiments (following those of Fritsch and Hitzig) on cerebral localisation, which were carried out at the laboratory on dogs and monkeys, and laid the basis of our knowledge of the localisation of function in the human brain cortex. The West Riding Asylum Medical Reports were the first English journal of neurology and neuropathology.

In I875 Crichton-Browne was appointed Lord Chancellor's Visitor in Lunacy, and the duties of that very responsible post, carried out with scrupulous care and understanding sympathy as in all his work for the mentally afflicted, engaged his activities for nearly half a century, till 1922 , but by no means absorbed his abounding energies. He soon became a feature of London social and public life, and no gathering of medical or of scientific men seemed complete without him. In I878, along with Hughlings Jackson, Sir John Bucknill, and Sir David Ferrier, he founded and co-edited Brain as a special journal devoted to neurological research In I 880 he became a member of the Royal Institution of Great Britain, of which he was afterwards honorary treasurer, from 1889 to 1926 , and vice-president. He had already been elected F.R.S.E. in I870, and in 1883 he was elected F.R.S., being originally proposed by Sir John Bucknill and seconded by Charles Darwin. In I886 he was created a Knight Bachelor by Queen Victoria. Among his other distinctions and honours he was President of the MedicoPsychological Association (I878), Neurological Society (I888), Medical Society of London (I895), National Health Society, and Sanitary Inspectors Association, and a Chadwick Trustee. He had conferred on him the degrees of LL.D. of St Andrews (1879), Aberdeen (1906), and Edinburgh (1933), and of D.Sc. of Leeds (I909). He was also a Fellow of the New York Academy of Medicine, and in 1893 he was elected to the Athenæum Club.

N.S. IV. XLV. NO. IV.

297

$\mathrm{x} 2$ 


\section{Obituary}

He was the oldest Freeman of Dumfries and also a Justice of the Peace for Dumfriesshire.

Sir James thoroughly realised that research was essential for progress in medicine as in science, and assiduously did all in his power to promote it. Apart from his great work in and for psychiatry and neurology, he was interested in the whole field of medicine and science, and particularly in matters concerning public health and sanitation and the public weal, including education. The cholera epidemic in Dumfries in I848, carrying off 430 lives, but fortunately, owing to his father's wise foresight and precautions, not involving the Crichton, made a deep impression on his child's mind. It was his first lesson in practical sanitation and a demonstration of the necessity of a pure water supply for the people, and it laid the seeds of his lifelong interest in public health matters. The great advances since made in hygiene, both physical and mental, owe much to his advocacy. There is hardly any subject bearing on the promotion of healthy living and healthy thinking on which he did not make some striking public pronouncement. Gifted in full measure with the barrister's faculty for mastering a brief, and armed with the invincible spear of sound reason, he did a great deal in his constant succession of addresses, papers, reports, and letters to the Press, to secure general attention for reforms which, though based on advances in medical science, would have made little headway unless backed by the force of enlightened public opinion. Many of his recommendations became incorporated in Acts of Parliament. Thus in 1883 he contributed a classic article on "Education and the Nervous System" in Malcolm Morris's Book of Health, which aroused considerable attention at a time when murmurs were being heard about overpressure in elementary schools and under-feeding of school-children. Two years later Mr Mundella, Vice-President of the Council, invited Dr Crichton-Browne to enquire and report on the matter in elementary schools in London. His able Report did not prove agreeable to the Vice-President and his Department, and so was expeditiously pigeon-holed; but ultimately it was ordered to be published as a Parliamentary Paper, when it at once took the country by storm; and Dr Crichton-Browne's work really sounded the death-knell of the pernicious system of payment by results in education. Fully thirty years afterwards Sir James summed up his attitude in the dictum-"Education is no doubt essential, but feeding comes before education, and breeding before that." He strongly urged the study of the psychology of childhood, to which period the origins of mental illness can so often be traced; and he was probably the first to stress the importance of the recognition of the premonitory symptoms of mental breakdown, and of the application of early or "first-aid" treatment in mental illness. He also supported later the campaigns for the open-air treatment of tuberculosis, and for 


\section{Obituary}

the control of venereal disease, by making the necessary sanitary measures available for the public; and as long ago as the beginning of the century he advocated the better housing of the working classes as the best means of improving the physique and morale of the people.

Apart from his many contributions to the literature of mental and nervous diseases and other fields of medicine, science, and education, Sir James was a man of wide reading and marked literary culture and ability. For Shakespeare, Scott, Carlyle, Burns, and Barrie, he had a deep veneration. For Dumfries and its associations he had the warmest affection, and during the Easter, Autumn and Christmas vacations it was his wont to seek quiet and recuperation at Crindau from his busy London life He was the champion of Carlyle, whom he knew intimately; and in The Nemesis of Froude, published in 1903 , he vigorously attacked Froude for his treatment of the relations between Carlyle and his wife. He was also the vindicator of Burns, whom, in a series of articles first appearing in The Glasgow Herald in December 1925 and afterwards in book form (Burns from a New Point of View), he clearly proved-from the evidence of the Poet's own letters - to have suffered from chronic rheumatism and to have died from endocarditis, instead of as previously reputed from drink, a wholly undeserved and calumnious charge originating from his early biographers, the censorious cleric, Heron, and in particular the teetotal and Calvinistic physician, Currie. Towards the close of his active life Sir James wrote six charming volumes of miscellanies in reminiscent vein, beginning with Victorian Jottings in I926 and ending with From the Doctor's Notebook in 1937. Sir James was a man of remarkable physical and mental vitality.
Even in his eighties he comfortably weathered two serious abdominal operations, the last at 85 for appendicitis. After entering his nineties -and he looked cheerfully forward to reaching his centenary-he gave the following secret and recipe for long life and happiness: "I am over ninety years of age, and am well and fit. There is no aspect of life which I cannot enjoy, and if you were to ask me as to what I owe my good health I would sum it up in one word-moderation. I have no fads at all in life. I am not a vegetarian, and I am not an abstainer. Indeed I like a little red wine, and when I go to Scotland I am not at all averse to a little whisky. The modern craze for rushing off to the sun for all manner of ailments may, I consider, be carried too far. As I live seven months of the year in England and five months in Scotland, and keep in excellent health, it certainly looks as if following the sun were not necessary in my own case. and The best recipe for a bright and happy life is work. Work and plenty of it is the best cure you can have for many ailments. I myself have had a hard working life . . . and apart from my work . there have always been literary interests to turn to. ... All 


\section{Obituary}

my life I have been fond of exercise, but now I confine it mainly to walking. I like motoring too, and find it beneficial for the mental as well as the physical stimulus it gives. . . . I can honestly say that I feel full of vigour, and am happy in retaining the spirit of youth which still makes me eager to undertake any adventure that may come to me on the journey of life."

Of medium height and build, Sir James had a neat and debonair figure, alert carriage, light and active gait, and a courtly presence, and he was probably the last to wear a pair of flowing Victorian whiskers, which made him conspicuous wherever he went. Naturally he often caught the eye of the cartoonist, whose caricature of his "Dundrearys" in Punch or elsewhere amused no one more heartily than Sir James himself. The Last of the Great Victorians, he brought the grace of that past age into modern life. Apart from his exceptional intellectual gifts and wonderful memory, which he retained to the last, his vision and imaginative powers, his clinical acumen and practical sagacity, and the charm of his manner, the outstanding traits of his personality were his great-heartedness and affection, his kindness and generosity, his sympathy and understanding, his consideration for others and his courtesy, and his interest in everybody and in everything. It was one of his own sayings that intellect without emotion is parched and pithless. He never forgot his friends and grudged no trouble to serve them and others who sought his help or advice.

He was a gifted orator and ready writer, lucid, dignified, eloquent and graceful, using the happy rounded phrase with ease and distinction, and not averse at times to the resounding words and rolling periods of the Gladstonian school of oratory. His rich and vivid vocabulary gave colour and point to all he spoke and wrote. Like many of the famous orators of the past, he prepared his speeches carefully, committed them to memory and rehearsed their delivery. He was also one of the best of after-dinner speakers of his day, buoyant and racy, humorous and witty, and rich in reminiscence and story and the apt quotation. Although he eschewed party politics he was a firm Constitutionalist and Conservative, but of the modern progressive school. Recognising religiosity as the supremely human faculty, and one which attains its highest development in the best races, and at the best periods of their history, he was opposed to godless government and education. He was a devout Episcopalian, and the senior member and faithful attender of St John the Evangelist's Church in Dumfries, where he was baptised.

In spite of considerable deafness in his closing years, followed by gradual impairment of eyesight, Sir James continued his literary activities to the end; and likewise he conducted his voluminous private correspondence in his characteristic flowing round hand till within hail of his ninety-seventh birthday, when he had to resort to 


\section{Obituary}

the aids of the amanuensis and the typewriter. A facsimile of his signature in his ninety-seventh year is shown herewith, below his portrait.

To a man of Sir James's loving nature the death of his only brother in I92 I, Mr J. H. Balfour Browne, K.C., of Goldielea, a neighbouring property to Crindau, came as a great blow in his eighty-first year. The death last October of his only and beloved son, of whom he was very proud, was a crushing blow at his great age, from which he never recovered. He had been in failing health for some months, and at the end he passed away suddenly from heart failure.

Sir James was twice married. In 1865 he married Emily, the youngest daughter of the late Dr Halliday, who was the scion of an old Galloway family, the Hallidays of Kirkland and Gelston. By that marriage there were two children, a son and a daughter; his Son, who died last October, was Colonel Harold William Alexander Francis Crichton-Browne, also a Freeman of Dumfries, who in his younger days accompanied the explorer, Joseph Thomson, in his expedition to Morocco and the Atlas Mountains, and afterwards had a distinguished military career in South Africa and in the Great War, and commanded the 3 rd K.O.S.B. from I9I I to I9I8; and his daughter is Mrs Florence Crichton-Browne or Taylor, widow of Captain J. W. Taylor. Sir James's first wife died in I903, and his second, whom he married in I9I2, and who survives him, was Audrey Emily, eldest daughter of the late General Sir Edward Bulwer, G.C.B., and great-niece of Bulwer Lytton. Sir James lost both his grandsons in the Great War.

C. C. Easterbrook. 